\title{
Use of Probiotic Preparations in Waste Waters Cleaning of Agricultural Enterprises
}

\section{Natalia Sannikova and Olga Kovaleva}

Federal State Budgetary Educational Institution of Higher Education State Agrarian University of Northern Trans-Urals, Tyumen, Russia

\section{Abstract}

The main cause of pollution of water basins is the discharge of untreated or insufficiently treated sewage into water bodies by industrial enterprises, utilities and agriculture. There are environmental problems in many enterprises of the country engaged in the production and processing of agricultural products. The article analyzes the results of research on the use of the Microbiological Cleaning System in model experiments. According to the results of model experiments, the optimal concentration of use of the drug was determined. Based on the results of the research, we propose the use of the Microbiological Purification System for pre-treatment of wastewater, even in the case of heavy pollution. Agriculture is an industry that is a source of environmental

Corresponding Author:

Natalia Sannikova

sannikova-nv7@bk.ru

Received: 25 October 2019

Accepted: 15 November 2019

Published: 25 November 2019

Publishing services provided by

Knowledge E

(c) Natalia Sannikova and Olga

Kovaleva. This article is

distributed under the terms of

the Creative Commons

Attribution License, which

permits unrestricted use and

redistribution provided that the

original author and source are

credited.

Selection and Peer-review under the responsibility of the AgroSMART 2019 Conference Committee. pollution. Purification of hazardous waste in enterprises can be accomplished through the introduction of biotechnology using probiotic preparations. The use of probiotics in the field of wastewater treatment is a relatively new direction that does not have much knowledge. The prospect of probiotic preparations for wastewater treatment is now being studied by many authors. As a result of the research, it was noted that the probiotic preparation intensifies the processes of biological wastewater treatment, which allows significantly reducing the intensity of odor and color of wastewater. As a result of the research conducted, the prospect of using probiotic preparations has been established.

Keywords: purification; waste water; probiotic preparations; agro-industrial enterprises; reservoirs, water, pollutants.

\section{Introduction}

Nowadays, environmental pollution is a recognized negative impact on the environment of industrial facilities (including agro-industrial). The sustainability of natural and agrosystems has reached a critical level and, as a result, the health of the population is deteriorating [14].

When implementing large-scale investment projects related to the construction of new facilities, the modernization of existing production and the implementation of environmental remediation measures, the need to improve the efficiency of work on 
Increasing requirements for economic efficiency and environmental standards for food production leads to the fact that traditional methods of cleaning industrial premises, livestock farms, waste water and storage waste production are either very expensive or inefficient in modern conditions. The presence of environmental problems in many enterprises of the country engaged in the production and processing of agricultural products is confirmed by the studies of many authors [3, 7--9, 13, 14].

The main cause of pollution of water basins is the discharge into the reservoirs of untreated or insufficiently treated wastewater by industrial enterprises, utilities and agriculture, as well as the increased incidence of oil spills into water bodies [4].

Most studies offer a description of the processes that occur during wastewater treatment using probiotics $[1,2,10]$. At the same time, there is practically no study of the possibilities of technological implementation of the studied processes.

World practice of their use has shown that the drugs are very effective for increasing the yield of agricultural crops, reducing their incidence and, to some extent, improving the quality characteristics of the products obtained [11].

In order to propose the technology of using the Microbiological Cleaning System (MBPS), we conducted model experiments. According to the results of the experiments, the technology of using probiotic preparations was proposed and tested. The peculiarity of our research is that wastewater is formed as a result of the activities of an agricultural enterprise.

\section{Methods and Equipment}

Currently the use of biodestructive organisms (bioremediation) is relevant [6]. The effect of probiotics by the method of "competitive crowding out" is such that probiotic bacteria are introduced into the studied environment, which leads to their immediate spread. They swiftly absorb all the remaining food (including dead organic material through necrotrophy), leaving nothing to potential pathogens seeking to find habitat and food [14]. The purpose of the research is to evaluate the use of the Microbiological Purification System (MBPS) in sewage treatment from the activities of an agricultural enterprise.

The objects of research are the storage ponds of an agricultural enterprise, intended for the accumulation of wastewater of a food industry enterprise engaged in the processing of milk and the production of dairy products. These objects are accumulators of the closed type and artificially created, intended only for discharge of sewage.

At the plant, water is used for: boiler room operation (heating and steam generation); production needs; household needs. 
During the activity of the enterprise, wastewater is formed in the amount of 289 $\mathrm{m}^{3} /$ day $\left(105485 \mathrm{~m}^{3} /\right.$ year), it contains detergent and disinfecting solutions $\left(\mathrm{NaOH}, \mathrm{HNO}_{3}\right)$. Drainage of the enterprise's wastewater is carried out via a recessed sewage system into an underground reinforced concrete clarifier and then by machines into a storage pond. Reset all year round.

A probiotic preparation was chosen as the Microbiological Purification System (MBPS). The specified drug is a liquid containing a large number of bacteria of the genus BACILLUS, which are representatives of obligate microflora $[8,16]$. This preparation contains 5 families: Bacillus subtilis, Bacillus subtilis var amyloliguefaciens, Bacillus licheniformis, Bacillus pumilus, Bacillus megaterium, and enzymes. Bacteria of the genus Bacillus produce antibacterial substances and are antagonists against pathogens, capable of producing a wide range of enzymes that break down fats, carbohydrates and fiber, and are also environmentally friendly.

\section{Results}

The studies using a probiotic preparation were conducted by Nasonkina N. G., Markin V.V. (2014, 2017). The studies were conducted in a laboratory setup: option 1 - with the addition of probiotics and option 2 - without the addition of probiotics [10]. According to the research Nasonkina N.G., Markina V.V. (2014) noted that contamination of wastewater was reduced more intensively compared with the reference capacity. For example, a decrease in the COD in the first variant was noted by $35.3 \%$, and in the control capacity by $2.3 \%$. Suspended substances decreased by $40.9 \%$ in the first variant and by $25.6 \%$ in the second. It follows that the addition of probiotics significantly reduced the indicators of contamination in wastewater $[12,13]$.

In our studies, the selection and preservation of wastewater samples from storage ponds were carried out in accordance with GOST 31861-2012, GOST 31862-2012, GOST 17.1.5.05-85. Chemical analysis carried out on 6 indicators according to (ND on the test method): suspended solids (RD 52.24.468-2005), ammonium nitrogen (GOST 29304), phosphates (GOST 18309), BOD5 (PND F 14.1: 2: 3: 4.123), COD (PND F 14.1: 2: 4.190), mass concentration of fats (PND F 14.1: 2.122). According to the results of samples taken in storage ponds, the increase in the concentrations of pollutants by suspended substances is observed by 4.1 times, chloride ions by 1.2 times, phosphates by 1.1 times, fats by 10 times, which significantly exceeds the maximum allowable concentrations. These data served as the initial source for conducting model experiments. 
For model experiments, various concentrations of MBPSs have been proposed. At the same time, mother liquor was prepared daily at the rate of $0.1 \%, 0.01 \%, 0,001 \%$ of the Microbiological Purification System.

The scheme of the model experiment is presented in Table 1. The experiment was conducted for 4 days.

TABLE 1: Scheme of the model experiment.

Experiment 1 (separator + MBPS)
$0,1 \% \quad 0,01 \% \quad 0,001 \%$
The separator was introduced
into the effluent without diluting
$-2 \%$ per volume of effluent.
Soaked in this form for 1 day.
After one day, different
concentrations of the stock
solution were added.

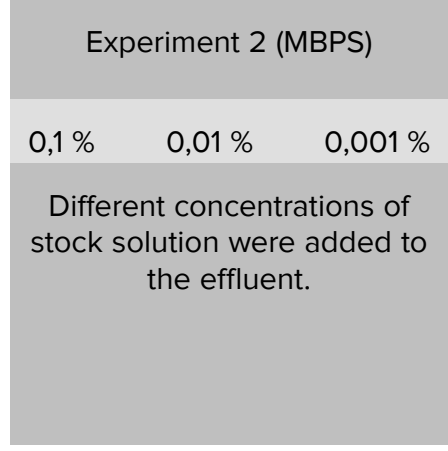

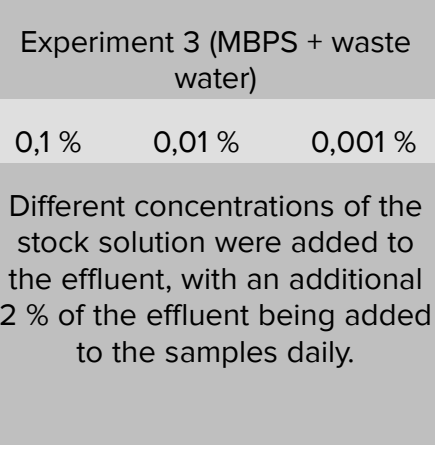

Experiment 3 (MBPS + waste water)

Different concentrations of the stock solution were added to the effluent, with an additional $2 \%$ of the effluent being added to the samples daily.

Chemical analyzes have shown that after 4 days, the amount of pollutants (pollutants) in the wastewater has changed significantly.

According to the results of the $1^{\text {st }}$ experiment (a separator + MBPS) a decrease in the concentrations of pollutants was observed in all indicators, with the exception of suspended substances in a concentration of $0.1 \%$ and $0.01 \%$. At the same time, the best result was shown by the concentration of $0.01 \%$ by phosphate $(67 \%), \mathrm{BOD}_{5}(95$ $\%)$ and the mass concentration of fat (73\%) (Table 2).

TABLE 2: Dynamics of changes in the composition of wastewater (separator + MBPS).

Indicators, units
Suspended substances,
$\mathrm{g} / \mathrm{dm}^{3}$
Ammonium nitrogen, \%
Phosphates, $\mathrm{mg} / \mathrm{dm}^{3}$
$\mathrm{BOD}_{5}, \mathrm{mgO}_{2} / \mathrm{dm}^{3}$
$\mathrm{COD}, \mathrm{mgO}_{2} / \mathrm{dm}^{3}$
$\mathrm{Mass} \mathrm{concentration}$ of
fat, $\mathrm{mg} / \mathrm{dm}^{3}$

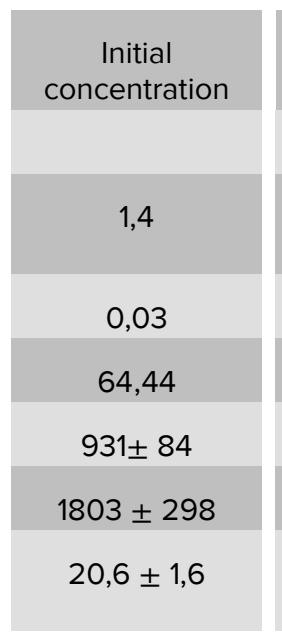

\begin{tabular}{|c|c|c|}
\hline \multicolumn{3}{|c|}{ Experiment 1 (separator + MBPS) } \\
\hline $0,1 \%$ & $0,01 \%$ & $0,001 \%$ \\
\hline 8,83 & 2,53 & 0,82 \\
\hline 0,10 & 0,02 & 0,01 \\
\hline 26,820 & 21,72 & 23,61 \\
\hline $190 \pm 17$ & $50 \pm 5$ & $110 \pm 10$ \\
\hline $770 \pm 108$ & $755 \pm 106$ & $750 \pm 105$ \\
\hline $9,0 \pm 1,3$ & $7,1 \pm 1,0$ & $8,1 \pm 1,1$ \\
\hline
\end{tabular}

According to the results of the $2^{\text {nd }}$ experiment (MBPS) there was a decrease in the concentrations of pollutants in all indicators. At the same time, the best result was shown 
by the concentration of $0.001 \%$ for suspended substances (68\%), phosphates (76 \%), $\mathrm{BOD}_{5}(70 \%)$, COD (60 \%) (Table 3).

TABLE 3: Dynamics of changes in the composition of wastewater (MBPS).

Indicators, units
Suspended substances,
$\mathrm{g} / \mathrm{dm}^{3}$
Ammonium nitrogen, \%
Phosphates, $\mathrm{mg} / \mathrm{dm}^{3}$
BOD, $\mathrm{mgO}_{2} / \mathrm{dm}^{3}$
$\mathrm{COD}, \mathrm{mgO}_{2} / \mathrm{dm}^{3}$
Mass concentration of
fat, $\mathrm{mg} / \mathrm{dm}^{3}$

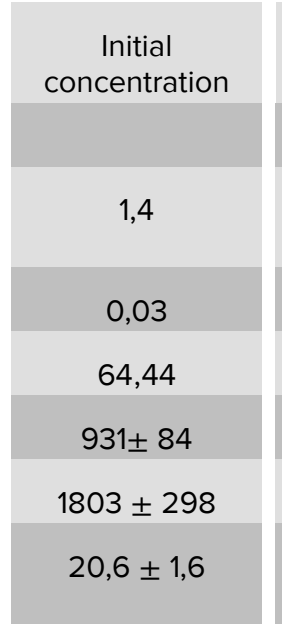

\begin{tabular}{|c|c|c|}
\hline \multicolumn{3}{|c|}{ Experiment 1 (MBPS) } \\
\hline $0,1 \%$ & $0,01 \%$ & $0,001 \%$ \\
\hline 1,30 & 0,99 & 0,44 \\
\hline 0,01 & 0,01 & 0,01 \\
\hline 20,76 & 18,25 & 15,34 \\
\hline $300 \pm 27$ & $440 \pm 40$ & $280 \pm 25$ \\
\hline $961 \pm 134$ & $1034 \pm 145$ & $727 \pm 102$ \\
\hline $3,8 \pm 0,3$ & $5,3 \pm 0,7$ & $7,6 \pm 1,1$ \\
\hline
\end{tabular}

According to the results of the 3rd experiment (MBPS + waste water), a decrease in the concentrations of pollutants was observed in all indicators, with the exception of suspended substances in a concentration of $0.1 \%$ and $0.01 \%$. At the same time, the best result was shown by the concentration of $0.001 \%$ in phosphates $(56 \%), \mathrm{BOD}_{5}$ (63\%), COD (55\%). A concentration of $0.1 \%$ by mass concentration of fat (74 \%) and suspended solids (almost $100 \%$ ) (Table 4).

According to the results of model experiments, the optimal concentration of the preparation of the Microbiological Purification System was determined -- $0.01 \%$.

According to the results of the model experiment, the optimal concentration of SMBO was established for use in real conditions and a scheme for the rehabilitation of ponds was proposed. We assume that the use of SMBO for pre-treatment of water is advisable even in the case of heavy pollution $[16,17]$.

During the production studies, wastewater samples were taken from July 11 to September 11.

The results of analyzes of wastewater samples are presented in Table 5. According to the research results, it was noted that from July 11, 2018 to September 11, 2018, the concentration of the following pollutants decreased: by suspended matter -- 17 times, by mass concentration of fats -- 17 times, for BOD5 -- 45 times, for COD -- 10 times, which corresponds to the indicators of hygienic standard.

According to the results of the research, the increase in the content of ammonium nitrogen was noted, which is associated with the activity of bacteria that decompose organic compounds in water. In this case, it is possible that protein compounds under the 
TABLE 4: Dynamics of changes in the composition of wastewater (SMBO + waste water).

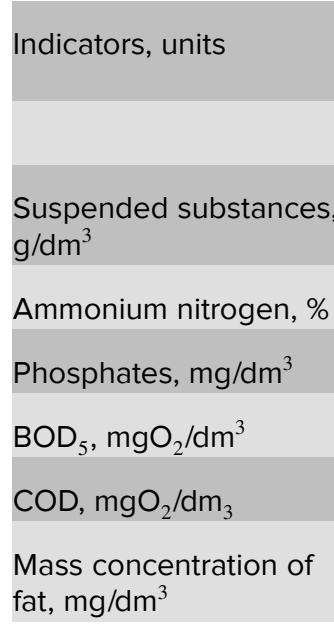

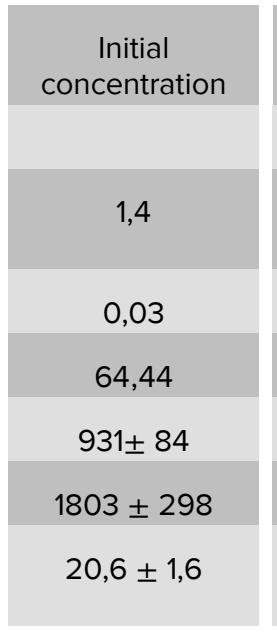

\begin{tabular}{|c|c|c|}
\hline \multicolumn{3}{|c|}{ Experiment 3 (MBPS + waste water) } \\
\hline $0,1 \%$ & $0,01 \%$ & $0,001 \%$ \\
\hline 1,39 & 1,840 & 1,55 \\
\hline 0,01 & 0,01 & 0,01 \\
\hline 30,36 & 32,97 & 27,8 \\
\hline $420 \pm 38$ & $430 \pm 39$ & $340 \pm 31$ \\
\hline $897 \pm 126$ & $1001 \pm 140$ & $806 \pm 113$ \\
\hline $5,2 \pm 0,7$ & $6,3 \pm 0,9$ & $8,0 \pm 1,1$ \\
\hline
\end{tabular}

TABLE 5: Results of the analysis of wastewater from the pond.

Indicators
$\begin{aligned} & \text { Suspended substances, } \\ & \mathrm{g} / \mathrm{dm}^{3}\end{aligned}$
Ammonium nitrogen, \%
Phosphates, $\mathrm{mg} / \mathrm{dm}^{3}$
$\mathrm{BOD}_{5}, \mathrm{mgO}_{2} / \mathrm{dm}^{3}$
$\mathrm{COD}^{3} \mathrm{mgO}_{2} / \mathrm{dm}^{3}$
Mass concentration of
fat, $\mathrm{mg} / \mathrm{dm}^{3}$

\begin{tabular}{|c|c|c|}
\hline \multicolumn{3}{|c|}{ Sampling date } \\
\hline 11.07 & 14.08 & 11.09 \\
\hline 1400 & 130 & 79 \\
\hline 300 & 100 & $>50$ \\
\hline 64,44 & 32,97 & 65,3 \\
\hline $931 \pm 84$ & $742 \pm 100$ & 20,5 \\
\hline $1803 \pm 298$ & $790 \pm 118$ & 176 \\
\hline $20,6 \pm 1,6$ & $12,2 \pm 1,7$ & $1,2 \pm 0,22$ \\
\hline
\end{tabular}

\begin{tabular}{c} 
Hygienic standard \\
\hline 300,0 \\
1,5 \\
12,0 \\
300,0 \\
500,0 \\
50,0
\end{tabular}

action of a high concentration of bacteria decompose with the formation of ammonium nitrogen in the anaerobic zones (which are always present).

Phosphates according to the research results steadily increased. Basically, it can be assumed that the presence of phosphates in waste water is caused by the death of biomass cells of activated sludge at any of the stages of biological oxidation. Explanation of these data requires further research. The changes in the status of the ponds are shown in Figure 1.

According to the results of research Polunina ON (2007), Nasonkina N.G. (2017) and other authors, it is noted that 300-400 thousand tons of sodium tripolyphosphate fall into water bodies annually. Only $1 \mathrm{~g}$ of this substance is enough to cause the growth of 5--10 kg of algae. The decomposition of algae produces methane, ammonia, hydrogen sulfide, which poison water and kill living creatures. In addition, phosphates provoke the formation of toxic cyanobacteria that cause intoxication. Excess phosphorus 
initiates the following chain: rapid plant growth, plant death, decay, oxygen depletion and deterioration of the life of organisms [11, 12].

In studies in all tanks, changes in the color and odor of wastewater were noted. The greatest clarification was observed in experiment 2, with a concentration of $0.01 \%$. The smell was very strong (5 points) on the first day of observation gradually decreased to noticeable ( 3 points) and weak ( 2 points). The nature of the smell on the scale is sulphurous, the genus of smell is rotten eggs and hydrogen sulfide has changed to the smell of natural origin.

As a result of observations on all variants of the experiment, the presence of a film of a whitish-gray color was noted, persisting throughout the experiment.

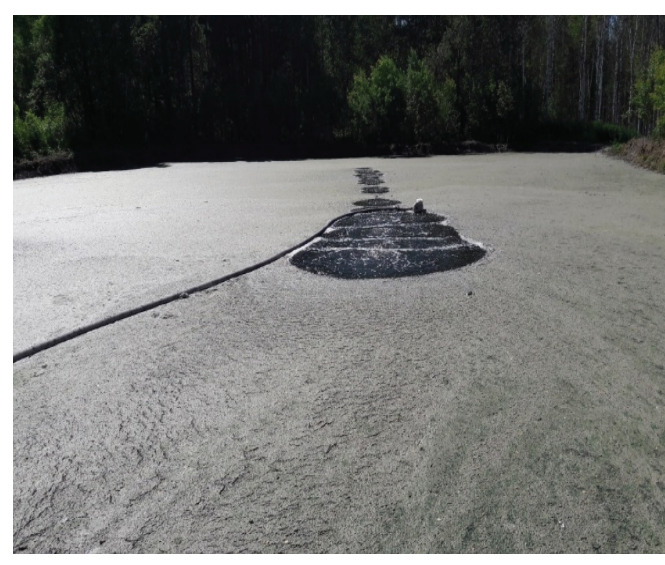

a

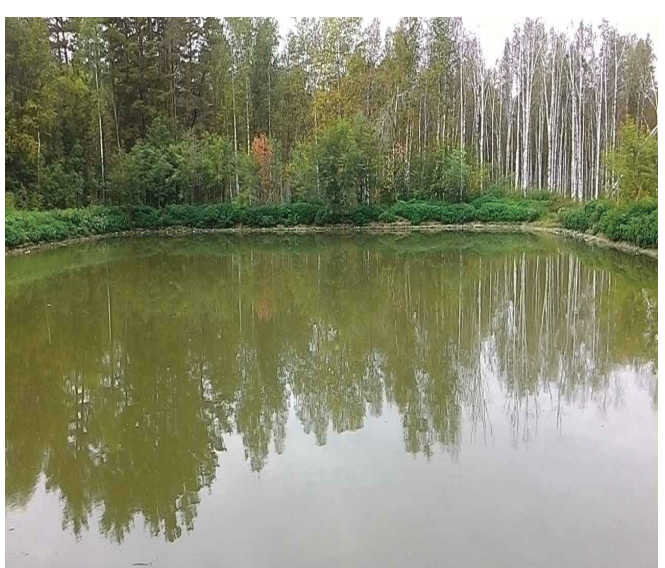

b

Figure 1: Changing the status of the effluent in the storage pond.

\section{Conclusion}

According to the results of the conducted model experiments, it can be noted that the use of the Microbiological Purification System (MBPS) containing the probiotic microflora for the preliminary purification of wastewater reduces the main indicators of water pollution. We assume that the use of MBPS for pre-treatment of water is advisable even in case of severe pollution.

In addition, the use of MBPSs can significantly reduce the intensity of odor, which indirectly may indicate a reduction in the release of toxic gases (ammonia, hydrogen sulfide) from the waste liquid. This may contribute to improving the sanitary safety of the facility. 
The advantages of probiotic agents can also be attributed to the absence of the risk of negative effects on the microbiocenosis of bottom sediments and the biocenosis around the storage pond.

As a result of the conducted research, the prospects of using the Microbiological Purification System were established, the optimal concentrations for use in real conditions were also determined.

\section{Conflict of Interest}

The authors have no conflict of interest to declare.

\section{References}

[1] Guo, H., Luo, S., Chen, L. et al. (2010). Bioremediation of heavy metals by growing hyperaccumulaor endophytic bacterium Bacillus sp. L14. Bioresour. Technol., vol. 101, no. 22, p. 8599.

[2] Dongarra, M.L., Rizzello, V., Muccio, L. et al. (2013). Mucosal immunology and probiotics. Curr. Allergy Asthma Rep. vol. 13(1), pp. 19--26. DOI: 10.1007/s11882- 0120313-0.

[3] Eremin, D.I. (2016). Changes in the Content and Quality of Humus in Leached Chernozems of the Trans-Ural Forest-Steppe Zone Under the Impact of their Agricultural use. Eurasian Soil Science, vol. 49, no. 5, pp. 538--545.

[4] Eremin, D., Eremina, D. (2016). Influence of Granulometric Composition Structure of Anthropogenic- reformed Soil on Ecology of Infrastructure. Procedia Engineering, vol. 165, pp. 788--793.

[5] Ilinsky, A.V., Vinogradov, D.V., Gogmachadze, G.D. (2016). On the issue of improving the efficiency of work on the rehabilitation of technologically polluted land through the introduction of a modern integrated control system. AgroEcolnfo, no. 3. Retrieved from: http://agroecoinfo.narod.ru/journal/STATYI/2016/3/st_320.doc

[6] Iglovikov, A. (2016). The Development of Artificial Phytocenosis in Environmental construction in the Far North. Procedia Engineering, vol. 165, pp. 800--805.

[7] Kiriy, O.A., Kolesnikov, S.I., Zinchuk, A.N. (2012). The use of the bacterial preparation Destroil in the elimination of contaminations of petroleum reservoirs with oil products. Scientific Journal KubSAU, no. 83(09).

[8] Kovaleva, O.V. (2018). Biotechnological products: opportunities and prospects of application. AgroEcolnfo, no. 4 (34), p. 2. 
[9] Kovaleva, O., Sannikova, N. (2018) Use of Biotechnological Preparations in Pig Breeding. International scientific and practical conference "Agro-SMART -- Smart solutions for agriculture" (Agro-SMART 2018). Advances in Engineering Research, vol. 151, pp. 383--390. DOI: 10.2991/agrosmart-18.2018.72

[10] Lilly D.M., Stillwell, R.H. (1965). Probiotics: growth-promoting factors produced by microorganisms. Science, no. 147(3659). pp. 747--748. DOI: 10.1126/science.147.3659.747

[11] Nasonkina, N.G.. Markin, V.V. (2017). Production research of the impact of probiotic means "OXIDOL" on wastewater treatment processes. Young Researcher of Don, no. 4(7), pp. 69--79.

[12] Nasonkina, N.G., Markin, V.V. (2014). Preliminary sewage treatment with probiotic agents. MOTROL. Commission of motorization and energetic in agriculture, vol. 16, no. 6, pp. 125--132 (Investigations of intensification of wastewater treatment using probiotic PIP PLUS WATER). Lublin: Polish Academy of Sciences.

[13] Polunina, O.N. (2007). Pollution of reservoirs by household chemicals. Ecology of Russia: on the way to innovations, interuniversity collection of scientific works, iss. 7, pp. 97--99.

[14] Sannikova, N.V., Kovaleva, O.V., Shulepova, O.V., Gogmachadze, G.D. (2018). Probiotic preparations in wastewater treatment. AgroEcolnfo, no. 4. Retrieved from: http://agroecoinfo.narod.ru/journal/STATYI/2018/4/st_469.doc.

[15] Sannikova, N., Kovaleva, O. (2018). Segmental Vegetation in the Wheat Agrophytocenosis of the Northern Transural Region. International scientific and practical conference "Agro-SMART - Smart solutions for agriculture" (Agro-SMART 2018). Advances in Engineering Research, vol. 151, pp. 621--3625. DOI: 10.2991/agrosmart18.2018.116

[16] Schur, A.V., Vinogradov, D.V., Gogmachadze, G.D. (2016). Ecological features of soil microbiota under conditions of radioactive contamination of the territory of the Republic of Belarus when using biologically active preparations. AgroEcolnfo, no. 1(23).

[17] Qiu, J., Wei, Y., Ma, Y., Wen, R., Wen, Y., Liu, W. (2014). A novel (S)-6-hydroxynicotine oxidase gene from Shinella sp. strain HZN7. Appl. Environ. Microbiol., vol. 80, no. 18, p. 5552. 